\title{
Molecular mechanisms of neuroinvasion by monocytes-macrophages in HIV-1 infection
}

\author{
Gabriel Gras*1 and Marcus Kaul2
}

\begin{abstract}
HIV associated neurocognitive disorders and their histopathological correlates largely depend on the continuous seeding of the central nervous system with immune activated leukocytes, mainly monocytes/macrophages from the periphery. The blood-brain-barrier plays a critical role in this never stopping neuroinvasion, although it appears unaltered until the late stage of HIV encephalitis. HIV flux that moves toward the brain thus relies on hijacking and exacerbating the physiological mechanisms that govern blood brain barrier crossing rather than barrier disruption. This review will summarize the recent data describing neuroinvasion by HIV with a focus on the molecular mechanisms involved.
\end{abstract}

\section{Introduction}

HIV-1 infection is often associated with neurocognitive impairment and the various degrees of severity have recently been categorized under the overarching term HIV associated neurocognitive disorders (HAND) [1]. HAND defines three categories of clinical disorders according to standardized measures of dysfunction: i) asymptomatic neurocognitive impairment (ANI), ii) mild neurocognitive disorder (MND) and iii) HIV-associated dementia (HAD) [2].

HAD constitutes the most severe form of HAND [1] which presented itself prominently at the beginning of the AIDS epidemic but primarily in patients with low CD4+ cell counts and advanced HIV disease [3]. Introduction of combination anti-retroviral therapy (cART)/ highly active antiretroviral therapy (HAART) in the mid 1990 improved treatment of HIV infection and often prevented or at least delayed the progression to AIDS and HAD. In recent years, however, and since HIV patients live longer, the incidence of dementia as an AIDS-defining illness has increased, and HAD now defines a significant independent risk factor for death due to AIDS $[4,5]$. While in the HAART era MND appears to be more prevalent than frank dementia, it appears important to take these long lasting disorders into account in patients' follow up as they may profoundly affect quality of life, com-

\footnotetext{
*Correspondence: gabriel.gras@cea.fr

1 Institute of Emerging Diseases and Innovative Therapies, Division of ImmunoVirology, CEA, 18 Route du Panorama, F92265 Fontenay-aux Roses, France Full list of author information is available at the end of the article
}

plicate autonomy, modify treatment compliance and induce a high level of vulnerability. Moreover, clinical observations over more than 10 years also suggest that HAART cannot completely protect from HAD [1,4-7]. In addition, it is possible that life-long treatment with HAART itself generates a toxicological problem which may affect neurocognitive performance on its own $[5,8]$.

The neuropathological correlates of HIV-1 infection are generally referred to as HIV encephalitis (HIVE) and comprise microglial nodules, activated resident microglia, multinucleated giant cells, infiltration predominantly by monocytoid cells, including blood-derived macrophages, widespread reactive astrocytosis, myelin pallor, and decreased synaptic and dendritic density in combination with distinct neuronal loss [9-11]. HIV-1 associated neuronal damage and loss have been reported for numerous regions of the central nervous system (CNS), including frontal cortex [12,13], substantia nigra [14], cerebellum [15], and putamen [16].

The neuropathology of HIV infection and AIDS has changed under the influence of HAART $[6,7,17]$. Neuroinflammation was commonly observed in HIV patients at the beginning of the AIDS epidemic and before the introduction of HAART, and usually increased throughout the progression of infected individuals from the latent, asymptomatic stage of the disease to AIDS and HAD [18]. Surprisingly, neuroinflammation seems to persist or even flourish since the advent of HAART $[17,19]$. Autopsy studies in recent years found microglial activation comparable to that in fully developed AIDS 
cases from the pre-HAART era, although the primary sites of neuroinflammation are seemingly changed. During pre-HAART times a strong involvement of the basal ganglia was observed whereas post-HAART specimen displayed prominent signs of inflammation in the hippocampus and adjacent parts of the entorhinal and temporal cortex [17]. Interestingly, HAART appeared to limit or even prevent lymphocyte infiltration into the CNS with the exception of the occasionally occurring immune reconstitution inflammatory syndrome (IRIS), that is characterized by massive lymphocytosis, extensive demyelination and white matter damage $[6,17]$.

HIV-1 enters the brain early in the course of infection, presumably via infected macrophages and lymphocytes, and then persists primarily in perivascular macrophages and microglia $[11,20,21]$. The pathophysiological relevance of CNS invading lymphocytes in HAND remains to be established [22], but CD8+ T cells have been suggested to control intrathecal HIV replication [23]. In contrast to lymphocytes, an increased number of microglia and macrophages correlates well with the severity of pre-mortem HAND $[11,18,24]$.

Infection of the CNS by HIV-1 can be detected and monitored by measurement of viral RNA in cerebrospinal fluid (CSF). Several groups have reported a positive correlation between CSF viral load and the observed degree of cognitive dysfunction in patients with HAND [25-27]. Moreover, CSF viral load appears to correlate with viral load in brain measured by quantitative PCR $[27,28]$, and the highest concentrations of virus are observed in those subcortical structures most frequently affected in patients with severe HAND/HAD [28].

However, in addition to initial neuroinvasion and infection of perivascular macrophages and microglia, factors associated with progressive HIV infection in the periphery, thus outside the brain, may be required to eventually trigger the development of HAND and dementia [29]. One such factor could be an elevated number of circulating monocytes expressing two markers of activated monocytes, CD16 and CD69. Another important player may be the blood brain barrier (BBB) which separates the CNS from the periphery and supposedly controls the traffic of low-molecular-weight nutrients, peptides, proteins and cells in and out of the brain (see for BBB review [30]). Thus the condition of the BBB may potentially determine continuing or repeated neuroinvasion during the course of HIV disease. However, the molecular mechanisms underlying HIV neuroinvasion are only slowly emerging. This review will discuss recent progress in studies of cellular and molecular factors affecting HIV neuroinvasion and consequent neurocognitive sequelae.

Peripheral Factors Influencing HIV-1 Neuroinvasion While interferons (IFNs) are important for an anti-viral immune response, the lasting production of IFN $-\alpha$ and $-\gamma$ in HIV-1 infection has been linked to an erroneous and exhaustive immune activation leading eventually to immune suppression and progression to AIDS [31-33]. In addition, the sustained presence of IFN- $\alpha$ in the HIVinfected CNS correlates with neurocognitive impairment $[34,35]$. Therefore, IFNs appear to have indeed a major impact on the overall course of HIV disease and consequently also on the development of HAND. However, it is not well understood whether or not IFNs directly influence neuroinvasion of HIV-1. One possible effect may be the IFN-induced expression in the human BBB of APOBEC3G, which has been suggested to account for the limited ability of human brain microvascular endothelial cells (HBMEC) to support HIV-1 replication and thus dissemination into the central nervous system [36].

Peripherally circulating, activated CD16+CD69+ monocytes are prone to adhere to normal endothelium of the brain microvasculature; they transmigrate and might subsequently trigger a number of deleterious processes [29]. Moreover, CD16+ monocytes become an expanding immune cell population during HIV infection [37], particularly with progression to AIDS [38]. These CD16+ monocytes are also more susceptible to HIV infection than the CD16- subset and are the major HIV reservoir among monocytes in vivo [39,40]. In fact, CD16+ monocytes likely serve as a vector for HIV trafficking from the periphery into the brain $[29,41]$. Indeed, although most monocytes do not actively replicate the virus, the macrophages that differentiate from these infected monocytes likely produce large amounts of virus after they quit the circulation, considering that differentiated macrophages are more prone to replicating HIV than monocytes [42-48]. Furthermore, CD16+ monocytes/ macrophages can support HIV replication in T-lymphocytes [49] and may be sequestered by tissues expressing the $\delta$-chemokine Fractalkine $\left(\mathrm{Fkn} / \mathrm{CX}_{3} \mathrm{CL} 1\right)$, which include the brain besides lymph nodes and intestine [5052]. These activated monocytes that represent a latent provirus reservoir in the blood [40] thus may continuously re-seed the brain with infected macrophages and microglia. In addition, macrophages and microglia do replicate HIV in the brain $[11,20,21,53]$ and are not susceptible to the virus' cytopathic effects $[54,55]$ thus permitting them to produce virions throughout their long life span [56-58].

In both HIVE and simian immunodeficiency virus encephalitis (SIVE), CD163+/CD16 ${ }^{+}$macrophages are detected in the parenchyma of the brain and seem to represent the primary productively infected cell population [53]. The elevated number of CD163 ${ }^{+} / \mathrm{CD} 16^{+}$monocytes/ macrophages may reflect an alteration of peripheral mononuclear cell homeostasis and is associated with increased viral burden and reduction of $\mathrm{CD} 4+\mathrm{T}$ cells. In SIV infection increased viral burden is associated with development of encephalitis, and suggests that the 
$\mathrm{CD} 163^{+} / \mathrm{CD} 16^{+}$monocyte/macrophage subset may be important in HIV/SIV-associated CNS disease [53]. The critical role of macrophages in the HIV-infected brain is further supported by the viral coreceptor usage. CCR5 is the main coreceptor for HIV infection of macrophages and microglia [59-61], and most virus isolates found in the brain or the CSF use CCR5 [60,62-68]. Of note, the very rare brain-derived R5X4 isolates exhibit tissue specific changes in the V3 region of gp120 that increase the efficiency of CCR5 usage and enhance their tropism for macrophages and microglia [69]. Moreover, macrophage tropism rather than $\mathrm{R} 5$ tropism appears to predict neurotropism [67], further emphasizing the role of these cells in NeuroAIDS.

One recent study used fluorescein-positive monocytes in acute simian immunodeficiency virus infection to track neuroinvasion [70]. In this study employing rhesus macaques, fluorescein dye-labeled autologous leukocytes were introduced in the periphery from where the cells subsequently entered into the choroid plexus stromata and perivascular locations in the cerebra during acute SIV infection. The infiltrated cells displayed both CD16 and CD68, both markers for macrophages and microglia. The neuroinvasion of monocytes occurred simultaneously with detectable amounts of virus in CNS tissue and CSF. Furthermore, neuroinvasion was accompanied by the appearance of the proinflammatory chemokines CXCL9/MIG and CCL2/MCP-1 in the brain. Interestingly, before neuroinvasion became obvious, plasma viral load peaked; counts of peripheral blood monocytes rapidly increased; and circulating monocytes displayed an elevated capacity to generate CCL2/MCP-1. Acute infiltration of monocytes into the brain is thus central in early neuroinvasion in the SIV animal model of AIDS. Besides a prominent role of migratory monocytes for SIV/HIV neuroinvasion, this study suggested that a disturbance occurs at the barriers between blood and brain parenchyma as well as blood and CSF [70].

As an alternative to HIV entry via infected macrophages, it has been suggested that the inflammatory cytokine TNF- $\alpha$ promotes a para-cellular route for the virus across the $\mathrm{BBB}$ [71]. However, in a study in the feline immunodeficiency virus model, cell-free FIV crossed the BBB only in very low quantities [72]. Moreover, the presence of TNF- $\alpha$ did not change viral transfer or compromise $\mathrm{BBB}$ integrity. In contrast, FIV readily crossed the $\mathrm{BBB}$ when cell-associated, yet without any significant impairment of the BBB. In response to TNF- $\alpha$, the migratory activity of uninfected and infected lymphocytes increased in association with an up-regulation of vascular endothelial adhesion molecule (VCAM)-1 and some detectable disturbance of the BBB. Interestingly, once infected cells and TNF- $\alpha$ were introduced on the abluminal side of the BBB in the brain parenchyma, an additional enhanced cell infiltration and more pronounced disruption of the BBB ensued. Moreover, the same study concluded that CNS invasion of lymphocytetropic lentiviruses is essentially very similar to that of macrophage-tropic strains [72].

HIV-1 infection compromises the structural integrity of the intestinal tract and can cause leakage of bacteria into the blood stream. Such microbial translocation results in elevated plasma levels of bacterial lipopolysaccharide (LPS), and in HIV-infected/AIDS patients, is associated with increased monocyte activation and dementia [7375]. Another study suggests that HIV infection increases the vulnerability of the BBB in response to LPS and facilitates the transmigration of peripheral monocytes/macrophages [76]. These findings support an important role for Toll-like receptors (TLRs) besides monocytes and macrophages in HAD $[75,76]$.

On the part of the host, a vicious cycle of immune dysregulation and $\mathrm{BBB}$ dysfunction might be required to achieve sufficient entry of infected or activated immune cells into the brain to cause neuronal injury $[77,78]$. On the side of the virus, variations of the envelope protein gp120 might also influence the timing and extent of events allowing viral entry into the CNS and leading to neuronal injury [79].

\section{Blood-Brain-Barrier (BBB)}

The $\mathrm{BBB}$ is widely believed to play an important role in HIV infection of the CNS $[29,80]$. For example, an acute relapsing brain edema with diffuse $\mathrm{BBB}$ alterations and axonal damage was observed early during the AIDS epidemic [81]; and the extravasation of plasma protein through an altered BBB has long been described in AIDS and HIVE cases [82]. In vivo, increased permeability of the BBB following HIV/SIV neuroinvasion is associated with the disorganization of tight junctions [83]. In particular zonula occludens (ZO-1) expression is modified in brains of patients with HIV encephalitis [71,84], and loss of occludin and claudin-5 correlates with areas of monocytes infiltration [85]. Such modifications of molecules involved in BBB structure are also found in the brain of SIV-infected macaques with SIVE $[86,87]$. Nevertheless, these profound modifications of the $\mathrm{BBB}$ structure appear to be late events associated with encephalitis whereas neuroinvasion is an early and continuing process.

Regarding the underlying molecular mechanisms involved in BBB crossing by HIV, it appears appropriate to consider in particular the following processes: HIVdependent cytotoxicity towards cellular BBB components, chemotaxis, regulation of adhesion molecules and tight junction proteins, and last not least the potential influence of drugs of abuse. 


\section{Cytotoxicity Towards Cellular BBB Components}

The HIV envelope protein gp120 apparently can trigger cytotoxicity in human brain microvascular endothelial cells (HBMEC) [88]. The process required the presence of IFN- $\gamma$ and activation of the p38 mitogen-activated protein kinase (MAPK). Interestingly, gp120-induced cytotoxicity occurred only in HBMEC from children but not from adults. The treatment with IFN- $\gamma$ resulted in an upregulation of the chemokine receptors CCR3 and CCR5 in HBMECs which in turn may have enhanced the toxic interaction with the viral envelope protein [88].

Interestingly, alterations in the BBB occur even in the absence of intact virus in transgenic mice expressing the HIV envelope protein gp120 in a form that circulates in plasma [89]. This finding suggests that circulating virus or envelope proteins may provoke BBB dysfunction at least during the viremic phase of primary infection.

\section{Chemotaxis}

Neurons, astrocytes and microglia all produce chemokines - cell migration/chemotaxis inducing cytokines such as monocyte chemoattractant protein CCL2/MCP-1 and $\mathrm{CX}_{3} \mathrm{CL1} / \mathrm{Fkn}$, which appear to attract peripheral blood mononuclear cells (PBMC) across the BBB into the brain parenchyma $[22,90]$.

In fact, an increased risk of HAD has recently been connected to a mutant MCP-1 allele that causes increased infiltration of mononuclear phagocytes into tissues [91]. In HIV/SIV infection, macrophages/microglia and astrocytes express increased quantities of MCP-1/ CCL2 [92-94], a chemokine that efficiently attracts monocytes across the BBB. Numerous cell types, including macrophages/microglia, astrocytes and endothelial cells, produce MCP-1 in response to inflammatory stimulation [95]. Of note, HIV infection of macrophages increased their expression of the CCL2 receptor, CCR2, and CCL2 mediated transmigration of HIV-infected PBMC reduced tight junction proteins occludin, claudin1 and ZO-1 expression in a BBB model in vitro [94]. Studies by numerous groups suggested CCL2 in the CNS as a key molecule for HIV encephalitis [96-100] during which it accumulates in the CSF and brain parenchyma $[97,101]$. Macaques with SIVE behave similarly [100,102,103]. Of importance in HIV infection [96] as well as in the SIV model [100] is that the CCL2 concentration rises in the CSF before neurological signs of the disease occur, conferring to the concentration of CCL2 a potentially prognostic value.

In a mouse model of HIVE based on animals with severe combined immunodeficiency (HIVE-SCID model), HIV-infected microglia and astrocytes seemed to regulate monocyte migration across the $\mathrm{BBB}$ via the release of $\beta$-chemokines [104]. On the other hand, stromal cell-derived factor (SDF)-1/CXCL12, an $\alpha$ - chemokine, has also been found to influence migration of monocytes by regulating attachment of the cells to HBMEC via the $\beta 2$ integrin lymphocyte function-associated antigen (LFA)- 1 in a Lyn kinase dependent fashion [105]. CXCL12 is up-regulated in neuroinflammatory diseases such as HAND/HAD or multiple sclerosis, and the same study found that the $\alpha$-chemokine concomitantly reduced monocyte adherence to intercellular adhesion molecule (ICAM)-1, which binds $\beta 2$ integrins. Interestingly, CXCL12 also counteracted the effect of TNF- $\alpha$, IL- $1 \beta$ and HIV gp120 regarding an increase of monocyte attachment to HBMEC due to an up-regulation of ICAM-1 [105]. In line with these observations and important for the better understanding of HIV-CNS disease, we found that nerve growth factor (NGF) promotes the attraction of monocytes by CXCL12 with a preferential effect on the CD16+ subset [106], while at the same time decreasing HIV-1 replication in the attracted and infected cells [107], suggesting a specific attraction of uninfected monocytes.

Using an in vitro model of the BBB comprised of endothelial cells and astrocytes, another study found that both CXCL12 and CCL2 promoted transmigration of uninfected monocytes and lymphocytes [108]. This investigation also revealed that HIV-1 transactivator of transcription (Tat) induced adhesion molecules and chemokines in astrocytes and microglia which may further increase the trafficking of PBMC into the brain. At the cellular level of monocytes and macrophages, the promigratory effect of CCL2 appears to involve $\mathrm{K}+$ channels [109].

A recent microarray study of HBMEC co-cultured with HIV-infected macrophages found the induction of numerous pro-inflammatory and IFN-inducible genes in comparison to endothelial cells exposed to uninfected immune cells [110]. In a separate investigation by the same group, HIVgp120 was observed to trigger in HBMEC the activation of signal transducer and activator of transcription (STAT)-1 and the release of interleukin (IL)-6 and IL-8 [111]. The eukaryotic interleukins and the viral gp120 promoted, in an in vitro BBB model, the attachment and transmigration of monocytes; and those processes were prevented by inhibitors of MAPKs, phosphatidyl-inositol 3 kinase (PI3K) or STAT-1 [111]. Furthermore, the pro-inflammatory and IFN-inducible gene products released by HBMEC upon exposure to HIV-1 have been found to down-regulate the expression of tight junction proteins claudin-5, ZO-1, and ZO-2 [112]. Interestingly, an increase of active STAT1 and a reduction of claudin- 5 were also found in microvessels of brain specimens from HAD patients [112]. Of note, the HIV-1 envelope protein gp120 seems to be able to trigger many of the effects leading to a compromised $\mathrm{BBB}$ and enhanced monocyte transmigration [113]. 
In line with the altered gene expression of HBMEC exposed to HIV-1 infected macrophages, a proteomic study found that over 200 proteins were up-regulated under the same conditions [114]. The affected cellular components included metabolic pathways, ion channels, cytoskeletal, heat-shock, calcium-binding and transportrelated proteins.

Translocation of bacterial LPS from the intestine in HIV-1 infection may not only promote the capability of peripheral monocytes to transmigrate into the brain, but may also encounter a BBB weakened by the effects of a systemic lentiviral infection. In a transgenic mouse model, JR-CSF/EYFP mice, expressing both a long terminal repeat-regulated full-length infectious HIV-1 provirus (JR-CSF) and a ROSA-26-regulated enhanced yellow fluorescent protein (EYFP) as transgenes, peripheral monocytes had an increased capability to enter the brain through an intact or partially compromised BBB [76]. Partial impairment of the BBB was induced by systemic LPS. Importantly, the BBB of JR-CSF/EYFP mice seemed more susceptible to disturbance by LPS than the BBB of HIV-1 free control animals. An earlier in vitro study by others found that placing LPS-stimulated macrophages on an artificial BBB led to the occurrence of gaps between endothelial cells and caused a significant increase in monocyte transmigration [115]. The activated monocytes released TNF- $\alpha$, IL- 6 and IL-10, but viral infection itself surprisingly did not increase transmigration under these conditions, suggesting that the LPS exerted a dominant effect. A more recent study found an alternate mechanism where LPS enhanced the trans-cellular transport of HIV-1 across the BBB via a p38 MAPK-dependent pathway [116].

Tryptophan metabolism via the kynurenine pathway occurs in the human BBB during HIV-1 infection and has been linked to immune tolerance and neurotoxicity [117]. Endothelial cells and pericytes of the BBB, as well as astrocytes [118], acquire upon immune stimulation the capability to produce kynurenine, which when released into the vicinity of macrophages and microglia could be further metabolized to the neurotoxin quinolinic acid [119]. Of note, IFNs and LPS are both able to activate tryptophan catabolism in macrophages [120], a process that may add to the effects of BBB activation during HIV infection. Thus, peripheral HIV-1 infection and associated immune stimulation side by side with LPS translocation could potentially exert neurotoxicity across the BBB even without the virus entering the brain.

\section{Adhesion Molecules}

Cell migration also engages adhesion molecules, and increased expression of various adhesion molecules, such as VCAM-1, has been implicated in mononuclear cell migration into the brain during HIV and SIV infection $[80,115,121,122]$. Astrocytes apparently control expres- sion of ICAM-1 in endothelial cells of the BBB, and upon exposure to TNF- $\alpha$, produce themselves ICAM-1, VCAM-1, IG9 and E-selectin, all of which may promote monocyte attachment and transmigration [121].

HIV-infected macrophages, in particular when additionally stimulated with LPS, induce expression of Eselectin and VCAM-1 in brain microvascular endothelial cells (BMEC) [80]. In brain specimens from AIDS patients with HIVE, detection of E-selectin and VCAM-1 correlated with HIV-1 and pro-inflammatory cytokines; and an association of invading macrophages and increased signal for endothelial adhesion molecules were observed in HIVE samples.

Possibly counteracting the effects of pro-inflammatory cytokines, the activation of peroxisome proliferator-activated receptor $\gamma$ (PPAR $\gamma$ ) in HBMECs can suppress the activity of Rho GTPases (Rac1 and RhoA) and inhibit adhesion and transendothelial migration of HIV-1 infected monocytes [123].

\section{Tight Junction Proteins}

Concomitant with the development of HIVE, the expression of tight junction proteins between BMECs of the BBB decreases. The disruption of tight junctions between BMECs is apparently mediated through the activation of focal adhesion kinase (FAK) by phosphorylation at TYR397 [124]. Furthermore, HIV-1 gp120 seems capable of inducing the disruption of tight junctions by triggering proteasomal degradation of ZO-1 and ZO-2 in HBMEC [125]. Interestingly, the scaffolding protein 14-3-3tau appears to counteract the down-regulation by HIV gp 120 of ZO-1 and ZO-2; and even more surprisingly, the viral envelope protein specifically increases expression of 143-3tau [125].

In addition to HIV gp120, Tat also affects tight junction proteins [126]. As such Tat reduces the expression of occludin, ZO-1, and ZO-2 in the caveolar compartment of HBMECs. The effect of Tat is dependent on caveolin-1 and its modulation of Ras signaling.

\section{Drugs of Abuse and Alcohol}

Abuse of psycho-stimulatory and addictive drugs seems to increase the risk of HIV-1 infection and of the development of HAND [127-130].

HIV Tat and morphine apparently cooperate in diminishing the electrical resistance and increasing the transmigration across the $\mathrm{BBB}$ via the activation of proinflammatory cytokines, the stimulation of intracellular $\mathrm{Ca}^{2+}$ release, and the activation of myosin light chain kinase [131]. A similar effect is caused by both methamphetamine and HIV gp120 either alone or in combination [132].

Cocaine also alters the expression of tight junction proteins and induces stress fibers in BMECs, and it in addition up-regulates the pro-migratory CCL2/CCR2 ligand- 
receptor system thus facilitating the passage of HIVinfected monocytes through the BBB [133]. In an in vitro BBB model comprising endothelial cells and astrocytes, cocaine was also found to decrease barrier function, increase expression of ICAM-1, VCAM-1 and plateletendothelial cell adhesion molecule (PECAM)-1, and to enhance monocyte migration across the BBB [134].

In contrast to the before-mentioned drugs, cannabinoids have been reported to preserve in HBMECs, in the presence of HIV gp120, the expression of tight junction proteins. Cannabinoids decrease the permeability of the $\mathrm{BBB}$ and inhibit the transmigration of HIV-infected monocytes through the barrier [135].

Alcohol and HIV-1 gp120 both affect BBB permeability and stress fiber formation in BMECs [136]. Interestingly, all these effects can apparently be ameliorated by the inhibition of reactive oxygen species [136].

\section{General considerations and conclusion}

HIV enters the CNS very early after infection, and then maintains its presence in the brain throughout the individual's life. Interestingly, major alterations of the $\mathrm{BBB}$ occur only late in HIV-CNS disease and thus initial seed- ing likely reflects the hijacking of physiological mechanisms of BBB crossing, such as the Trojan horse strategy initially proposed by Narayan and colleagues $[137,138]$. A model of the multistep, multifactorial process of CNS invasion by HIV-1, is illustrated in figure 1 . It has for years remained unclear whether the infected CNS constituted, after its initial seeding, a viral sanctuary independent of the periphery or just reflected infection features outside the brain. The introduction of HAART challenged our vision of the brain as an independent sanctuary of HIV infection because the lower incidence of HAD in treated patients, despite low brain penetration of the molecules, strongly suggested that HIV induced CNS disorders do require continuous immune activation in the brain and neuroinvasion of activated and/or infected leukocytes.

This interdependence is exemplified by the fact that, in humans and in animal models, neurological complications of HIV infection correlate not only with innate immunity [35] and macrophage/microglia activation $[11,18,24]$ within the brain tissue, but also with proviral load in activated peripheral CD16+ monocytes/macrophages $[29,40,41]$. In this context, BBB crossing by HIV

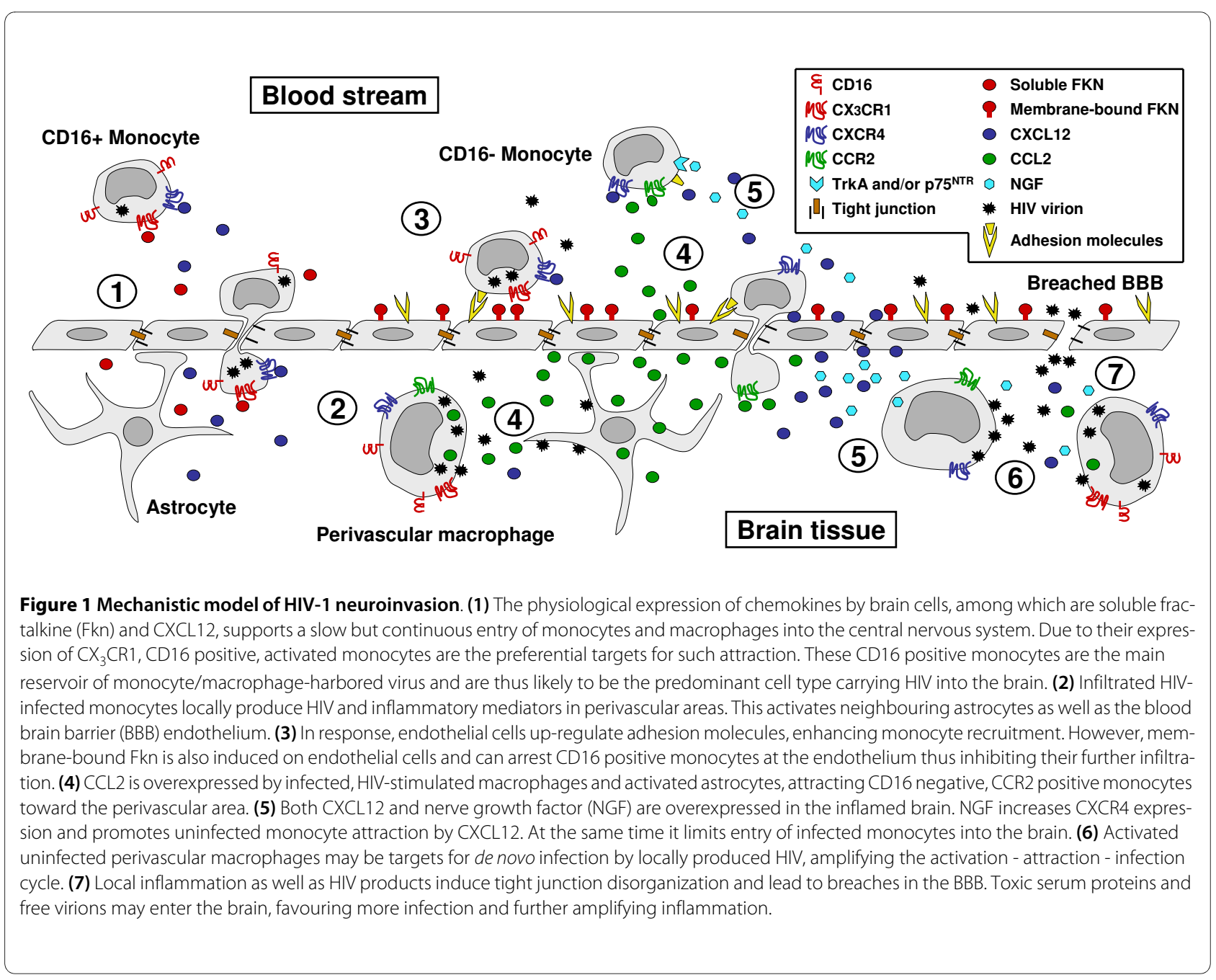


infected and immune-activated macrophages appears to be a critical target for future therapeutic developments. The very complex and intricate mechanisms that govern this crossing should thus be studied with particular attention.

HAND correlate with CSF viral load [25], which is closely related to CSF pleocytosis [139]. In a recent study, Sinclair et al. showed that HAART despite treatment failures with no effect on peripheral viral load, had nevertheless a significant beneficial impact on CSF viral load, CSF pleocytosis, and immune activation [140]. This striking and encouraging result further illustrates the critical importance of an improved understanding of BBB function and neuroinvasion mechanisms. Furthermore, HIV neuroinvasion and BBB likely will provide future therapeutic targets for coping with the anticipated increase in HAND prevalence as more and more HIV patients come of age.

\section{Competing interests}

The authors declare that they have no competing interests.

\section{Authors' contributions}

GG and MK wrote the article jointly. All authors read and approved the final manuscript.

\section{Acknowledgements}

This review was inspired by discussions of the role of the cells of the mononuclear phagocyte lineage in HIV infection during meetings conducted by the Association for Macrophage in Infection Research (AMIR). Article processing charges of this review are paid for by the Concerted Action 31 - Dendritic cells, Antigen Presentation and Innate Immunity of the "Agence Nationale de Recherche sur le Sida et les Hépatites Virales" (ANRS). M. Kaul was supported by $\mathrm{NIH}$ grant R01 NS050621. G. Gras was supported by grants from the "Agence Nationale de Recherche sur le Sida et les Hépatites Virales" (ANRS), the « Fondation pour la Recherche Médicale » (FRM) and « Ensemble Contre le Sida » (SIDACTION)

\section{Author Details}

IInstitute of Emerging Diseases and Innovative Therapies, Division of ImmunoVirology, CEA, 18 Route du Panorama, F92265 Fontenay-aux Roses, France and 2Infectious \& Inflammatory Disease Center, Burnham Institute for Medical Research, 10901 North Torrey Pines Road, La Jolla, CA 92037, USA

Received: 1 October 2009 Accepted: 7 April 2010

Published: 7 April 2010

\section{References}

1. Antinori A, Arendt G, Becker JT, Brew BJ, Byrd DA, Cherner M, Clifford DB, Cinque P, Epstein LG, Goodkin K, Gisslen M, Grant I, Heaton RK, Joseph J, Marder K, Marra CM, McArthur JC, Nunn M, Price RW, Pulliam L, Robertson KR, Sacktor N, Valcour V, Wojna VE: Updated research nosology for HIVassociated neurocognitive disorders. Neurology 2007, 69:1789-1799.

2. Ghafouri M, Amini S, Khalili K, Sawaya BE: HIV-1 associated dementia: symptoms and causes. Retrovirology 2006, 3:28.

3. McArthur JC, Hoover DR, Bacellar H, Miller EN, Cohen BA, Becker JT, Graham NM, McArthur JH, Selnes OA, Jacobson LP, et al.: Dementia in AIDS patients: incidence and risk factors. Multicenter AIDS Cohort Study. Neurology 1993, 43:2245-2252.

4. Ellis RJ, Deutsch R, Heaton RK, Marcotte TD, McCutchan JA, Nelson JA, Abramson I, Thal LJ, Atkinson JH, Wallace MR, Grant I: Neurocognitive impairment is an independent risk factor for death in HIV infection. San Diego HIV Neurobehavioral Research Center Group. Arch Neurol 1997, 54:416-424.
5. Liner KJ, Hall CD, Robertson KR: Effects of antiretroviral therapy on cognitive impairment. Curr HIV/AIDS Rep 2008, 5:64-71.

6. Boisse L, Gill MJ, Power C: HIV infection of the central nervous system: clinical features and neuropathogenesis. Neurol Clin 2008, 26:799-819. X

7. Brew BJ, Crowe SM, Landay A, Cysique LA, Guillemin G: Neurodegeneration and ageing in the HAART era. J Neuroimmune Pharmacol 2009, 4:163-174.

8. Letendre S, Marquie-Beck J, Capparelli E, Best B, Clifford D, Collier AC, Gelman BB, McArthur JC, McCutchan JA, Morgello S, Simpson D, Grant I, Ellis RJ, CHARTER Group: Validation of the CNS Penetration-Effectiveness rank for quantifying antiretroviral penetration into the central nervous system. Arch Neurol 2008, 65:65-70.

9. Adle-Biassette H, Bell JE, Creange A, Sazdovitch V, Authier FJ, Gray F, Hauw $\mathrm{JJ}$, Gherardi R: DNA breaks detected by in situ end-labelling in dorsal root ganglia of patients with AIDS. Neuropathol Appl Neurobiol 1998, 24:373-380

10. Masliah E, Heaton RK, Marcotte TD, Ellis RJ, Wiley CA, Mallory M, Achim CL, McCutchan JA, Nelson JA, Atkinson JH, Grant I: Dendritic injury is a pathological substrate for human immunodeficiency virus-related cognitive disorders. HNRC Group. The HIV Neurobehavioral Research Center. Ann Neurol 1997, 42:963-972.

11. Petito CK, Cho ES, Lemann W, Navia BA, Price RW: Neuropathology of acquired immunodeficiency syndrome (AIDS): an autopsy review. Neuropathol Exp Neurol 1986, 45:635-646.

12. Everall IP, Luthert PJ, Lantos PL: Neuronal loss in the frontal cortex in HIV infection. Lancet 1991, 337:1119-1121.

13. Ketzler $\mathrm{S}$, Weis $\mathrm{S}, \mathrm{Haug} \mathrm{H}$, Budka $\mathrm{H}$ : Loss of neurons in the frontal cortex in AIDS brains. Acta Neuropathol 1990, 80:92-94.

14. Reyes MG, Faraldi F, Senseng CS, Flowers C, Fariello R: Nigral degeneration in acquired immune deficiency syndrome (AIDS). Acta Neuropathol 1991, 82:39-44

15. Graus F, Ribalta T, Abos J, Alom J, Cruz-Sanchez F, Mallolas J, Miro JM, Cardesa A, Tolosa E: Subacute cerebellar syndrome as the first manifestation of AIDS dementia complex. Acta Neurol Scand 1990, 81:118-120

16. Everall I, Luthert P, Lantos P: A review of neuronal damage in human immunodeficiency virus infection: its assessment, possible mechanism and relationship to dementia. J Neuropathol Exp Neurol 1993, 52:561-566

17. Anthony IC, Bell JE: The Neuropathology of HIV/AIDS. Int Rev Psychiatry 2008, 20:15-24.

18. Glass JD, Fedor H, Wesselingh SL, McArthur JC: Immunocytochemical quantitation of human immunodeficiency virus in the brain: correlations with dementia. Ann Neurol 1995, 38:755-762.

19. Langford TD, Letendre SL, Larrea GJ, Masliah E: Changing patterns in the neuropathogenesis of HIV during the HAART era. Brain Pathol 2003, 13:195-210.

20. Ho DD, Rota TR, Schooley RT, Kaplan JC, Allan JD, Groopman JE, Resnick L, Felsenstein D, Andrews CA, Hirsch MS: Isolation of HTLV-III from cerebrospinal fluid and neural tissues of patients with neurologic syndromes related to the acquired immunodeficiency syndrome. $\mathrm{N}$ Engl J Med 1985, 313:1493-1497.

21. Koenig S, Gendelman HE, Orenstein JM, Dal Canto MC, Pezeshkpour GH, Yungbluth M, Janotta F, Aksamit A, Martin MA, Fauci AS: Detection of AIDS virus in macrophages in brain tissue from AIDS patients with encephalopathy. Science 1986, 233:1089-1093.

22. Asensio VC, Campbell IL: Chemokines in the CNS: plurifunctional mediators in diverse states. Trends Neurosci 1999, 22:504-512.

23. Sadagopal S, Lorey SL, Barnett L, Basham R, Lebo L, Erdem H, Haman K Avison M, Waddell K, Haas DW, Kalams SA: Enhancement of human immunodeficiency virus (HIV)-specific CD8+T cells in cerebrospinal fluid compared to those in blood among antiretroviral therapy-naive HIV-positive subjects. J Virol 2008, 82:10418-10428.

24. Anthony IC, Ramage SN, Carnie FW, Simmonds P, Bell JE: Influence of HAART on HIV-related CNS disease and neuroinflammation. $J$ Neuropathol Exp Neurol 2005, 64:529-536.

25. Brew BJ, Pemberton L, Cunningham P, Law MG: Levels of human immunodeficiency virus type 1 RNA in cerebrospinal fluid correlate with AIDS dementia stage. J Infect Dis 1997, 175:963-966.

26. Ellis RJ, Hsia K, Spector SA, Nelson JA, Heaton RK, Wallace MR, Abramson I, Atkinson JH, Grant I, McCutchan JA: Cerebrospinal fluid human immunodeficiency virus type 1 RNA levels are elevated in 
neurocognitively impaired individuals with acquired immunodeficiency syndrome. HIV Neurobehavioral Research Center Group. Ann Neurol 1997, 42:679-688.

27. McArthur JC, McClernon DR, Cronin MF, Nance-Sproson TE, Saah AJ, S Clair M, Lanier ER: Relationship between human immunodeficiency virus-associated dementia and viral load in cerebrospinal fluid and brain. Ann Neurol 1997, 42:689-698.

28. Wiley CA, Soontornniyomkij V, Radhakrishnan L, Masliah E, Mellors J, Hermann SA, Dailey P, Achim CL: Distribution of brain HIV load in AIDS. Brain Pathol 1998, 8:277-284.

29. Gartner S: HIV infection and dementia. Science 2000, 287:602-604.

30. Banks WA, Ercal N, Price TO: The blood-brain barrier in neuroAIDS. Curr HIV Res 2006, 4:259-266.

31. Cho YY, Astgen A, Hendel H, Issing W, Perrot JY, Schachter F, Rappaport J, Zagury JF: Homeostasis of chemokines, interferon production and lymphocyte subsets: implications for AIDS pathogenesis. Biomed Pharmacother 1997, 51:221-229.

32. Mandl JN, Barry AP, Vanderford TH, Kozyr N, Chavan R, Klucking S, Barrat FJ, Coffman RL, Staprans SI, Feinberg MB: Divergent TLR7 and TLR9 signaling and type I interferon production distinguish pathogenic and nonpathogenic AIDS virus infections. Nat Med 2008, 14:1077-1087.

33. Poli G, Biswas P, Fauci AS: Interferons in the pathogenesis and treatment of human immunodeficiency virus infection. Antiviral Res 1994, 24:221-233.

34. Sas AR, Bimonte-Nelson H, Smothers CT, Woodward J, Tyor WR: Interferon-alpha causes neuronal dysfunction in encephalitis. $J$ Neurosci 2009, 29:3948-3955.

35. Sas AR, Bimonte-Nelson HA, Tyor WR: Cognitive dysfunction in HIV encephalitic SCID mice correlates with levels of Interferon-alpha in the brain. Aids 2007, 21:2151-2159.

36. Argyris EG, Acheampong E, Wang F, Huang J, Chen K, Mukhtar M, Zhang $\mathrm{H}$ : The interferon-induced expression of APOBEC3G in human bloodbrain barrier exerts a potent intrinsic immunity to block HIV-1 entry to central nervous system. Virology 2007, 367:440-451

37. Thieblemont $N$, Weiss $L$, Sadeghi HM, Estcourt C, Haeffner-Cavaillon $N$ : CD14lowCD16high: a cytokine-producing monocyte subset which expands during human immunodeficiency virus infection. Eur $J$ Immunol 1995, 25:3418-3424.

38. Pulliam L, Gascon R, Stubblebine M, McGuire D, McGrath MS: Unique monocyte subset in patients with AIDS dementia. Lancet 1997, 349:692-695.

39. Coleman CM, Wu L: HIV interactions with monocytes and dendritic cells: viral latency and reservoirs. Retrovirology 2009, 6:51.

40. Ellery PJ, Tippett E, Chiu YL, Paukovics G, Cameron PU, Solomon A, Lewin SR, Gorry PR, Jaworowski A, Greene WC, Sonza S, Crowe SM: The CD16+ monocyte subset is more permissive to infection and preferentially harbors HIV-1 in vivo. J Immunol 2007, 178:6581-6589.

41. Shiramizu B, Gartner S, Williams A, Shikuma C, Ratto-Kim S, Watters M, Aguon J, Valcour V: Circulating proviral HIV DNA and HIV-associated dementia. Aids 2005, 19:45-52.

42. Kalter DC, Nakamura M, Turpin JA, Baca LM, Hoover DL, Dieffenbach C, Ralph P, Gendelman HE, Meltzer MS: Enhanced HIV replication in macrophage colony-stimulating factor-treated monocytes. J Immunol 1991, 146:298-306.

43. Naif HM, Li S, Alali M, Sloane A, Wu L, Kelly M, Lynch G, Lloyd A Cunningham AL: CCR5 expression correlates with susceptibility of maturing monocytes to human immunodeficiency virus type 1 infection. J Virol 1998, 72:830-836

44. Rich EA, Chen IS, Zack JA, Leonard ML, O'Brien WA: Increased susceptibility of differentiated mononuclear phagocytes to productive infection with human immunodeficiency virus-1 (HIV-1). J Clin Invest 1992, 89:176-183.

45. Schrier RD, Freeman WR, Wiley CA, McCutchan JA: CMV-specific immune responses and HLA phenotypes of AIDS patients who develop CMV retinitis. HNRC Group. HIV Neurobehavioral Research Center. Adv Neuroimmunol 1994, 4:327-336.

46. Schrier RD, McCutchan JA, Wiley CA: Mechanisms of immune activation of human immunodeficiency virus in monocytes/macrophages. JVirol 1993, 67:5713-5720

47. Sonza S, Maerz A, Deacon N, Meanger J, Mills J, Crowe S: Human immunodeficiency virus type 1 replication is blocked prior to reverse transcription and integration in freshly isolated peripheral blood monocytes. J Virol 1996, 70:3863-3869.

48. Wang X, Ye L, Hou W, Zhou Y, Wang YJ, Metzger DS, Ho WZ: Cellular microRNA expression correlates with susceptibility of monocytes/ macrophages to HIV-1 infection. Blood 2009, 113:671-674.

49. Ancuta P, Kunstman KJ, Autissier P, Zaman T, Stone D, Wolinsky SM, Gabuzda D: CD16+ monocytes exposed to HIV promote highly efficient viral replication upon differentiation into macrophages and interaction with T cells. Virology 2006, 344:267-276.

50. Ancuta P, Liu KY, Misra V, Wacleche VS, Gosselin A, Zhou X, Gabuzda D: Transcriptional profiling reveals developmental relationship and distinct biological functions of CD16+ and CD16- monocyte subsets. BMC Genomics 2009, 10:403.

51. Ancuta P, Moses A, Gabuzda D: Transendothelial migration of CD16+ monocytes in response to fractalkine under constitutive and inflammatory conditions. Immunobiology 2004, 209:11-20.

52. Ancuta P, Rao R, Moses A, Mehle A, Shaw SK, Luscinskas FW, Gabuzda D: Fractalkine preferentially mediates arrest and migration of CD16+ monocytes. J Exp Med 2003, 197:1701-1707.

53. Fischer-Smith T, Bell C, Croul S, Lewis M, Rappaport J: Monocyte/ macrophage trafficking in acquired immunodeficiency syndrome encephalitis: lessons from human and nonhuman primate studies. $J$ Neurovirol 2008, 14:318-326.

54. Gartner S, Markovits P, Markovitz DM, Betts RF, Popovic M: Virus isolation from and identification of HTLV-III/LAV-producing cells in brain tissue from a patient with AIDS. Jama 1986, 256:2365-2371.

55. Gartner S, Markovits P, Markovitz DM, Kaplan MH, Gallo RC, Popovic M: The role of mononuclear phagocytes in HTLV-III/LAV infection. Science 1986, 233:215-219.

56. Embretson J, Zupancic M, Ribas JL, Burke A, Racz P, Tenner-Racz K, Haase AT: Massive covert infection of helper T lymphocytes and macrophages by HIV during the incubation period of AIDS. Nature 1993, 362:359-362.

57. Martin JC, Bandres JC: Cells of the monocyte-macrophage lineage and pathogenesis of HIV-1 infection. J Acquir Immune Defic Syndr 1999, 22:413-429.

58. Orenstein JM, Fox C, Wahl SM: Macrophages as a source of HIV during opportunistic infections. Science 1997, 276:1857-1861

59. Alkhatib G, Combadiere C, Broder CC, Feng Y, Kennedy PE, Murphy PM Berger EA: CC CKR5: a RANTES, MIP-1alpha, MIP-1 beta receptor as a fusion cofactor for macrophage-tropic HIV-1. Science 1996, 272:1955-1958

60. Choe H, Farzan M, Sun Y, Sullivan N, Rollins B, Ponath PD, Wu L, Mackay CR, LaRosa G, Newman W, Gerard N, Gerard C, Sodroski J: The betachemokine receptors CCR3 and CCR5 facilitate infection by primary HIV-1 isolates. Cell 1996, 85:1135-1148.

61. Dragic T, Litwin V, Allaway GP, Martin SR, Huang Y, Nagashima KA, Cayanan C, Maddon PJ, Koup RA, Moore JP, Paxton WA: HIV-1 entry into CD4+ cells is mediated by the chemokine receptor CC-CKR-5. Nature 1996, 381:667-673.

62. Albright AV, Shieh JT, Itoh T, Lee B, Pleasure D, O'Connor MJ, Doms RW, Gonzalez-Scarano F: Microglia express CCR5, CXCR4, and CCR3, but of these, CCR5 is the principal coreceptor for human immunodeficiency virus type 1 dementia isolates. J Virol 1999, 73:205-213.

63. He J, Chen Y, Farzan M, Choe H, Ohagen A, Gartner S, Busciglio J, Yang X, Hofmann W, Newman W, Mackay CR, Sodroski J, Gabuzda D: CCR3 and CCR5 are co-receptors for HIV-1 infection of microglia. Nature 1997, 385:645-649.

64. Li S, Juarez J, Alali M, Dwyer D, Collman R, Cunningham A, Naif HM: Persistent CCR5 utilization and enhanced macrophage tropism by primary blood human immunodeficiency virus type 1 isolates from advanced stages of disease and comparison to tissue-derived isolates. J Virol 1999, 73:9741-9755.

65. Shieh JT, Albright AV, Sharron M, Gartner S, Strizki J, Doms RW, GonzalezScarano F: Chemokine receptor utilization by human immunodeficiency virus type 1 isolates that replicate in microglia. $J$ Virol 1998, 72:4243-4249

66. Smit TK, Wang B, Ng T, Osborne R, Brew B, Saksena NK: Varied tropism of HIV-1 isolates derived from different regions of adult brain cortex discriminate between patients with and without AIDS dementia complex (ADC): evidence for neurotropic HIV variants. Virology 2001, 279:509-526. 
67. Gorry PR, Bristol G, Zack JA, Ritola K, Swanstrom R, Birch CJ, Bell JE, Bannert N, Crawford K, Wang H, Schols D, De Clercq E, Kunstman K, Wolinsky SM, Gabuzda D: Macrophage tropism of human immunodeficiency virus type 1 isolates from brain and lymphoid tissues predicts neurotropism independent of coreceptor specificity. J Viro/ 2001, 75:10073-10089.

68. Gorry PR, Taylor J, Holm GH, Mehle A, Morgan T, Cayabyab M, Farzan M, Wang H, Bell JE, Kunstman K, Moore JP, Wolinsky SM, Gabuzda D: Increased CCR5 affinity and reduced CCR5/CD4 dependence of a neurovirulent primary human immunodeficiency virus type 1 isolate. $J$ Virol 2002, 76:6277-6292.

69. Gray L, Roche M, Churchill MJ, Sterjovski J, Ellett A, Poumbourios P, Sherieff S, Wang B, Saksena N, Purcell DF, Wesselingh S, Cunningham AL, Brew BJ, Gabuzda D, Gorry PR: Tissue-specific sequence alterations in the human immunodeficiency virus type 1 envelope favoring CCR5 usage contribute to persistence of dual-tropic virus in the brain. J Virol 2009, 83:5430-5441.

70. Clay CC, Rodrigues DS, Ho YS, Fallert BA, Janatpour K, Reinhart TA, Esser U: Neuroinvasion of fluorescein-positive monocytes in acute simian immunodeficiency virus infection. J Virol 2007, 81:12040-12048.

71. Fiala M, Looney DJ, Stins M, Way DD, Zhang L, Gan X, Chiappelli F, Schweitzer ES, Shapshak P, Weinand M, Graves MC, Witte M, Kim KS: TNFalpha opens a paracellular route for HIV-1 invasion across the bloodbrain barrier. Mol Med 1997, 3:553-564.

72. Fletcher NF, Bexiga MG, Brayden DJ, Brankin B, Willett BJ, Hosie MJ, Jacque $J M$, Callanan JJ: Lymphocyte migration through the blood brain barrier (BBB) in feline immunodeficiency virus infection is significantly influenced by the pre-existence of virus and TNF-alpha within the CNS: studies using an in vitro feline BBB model. Neuropathol App/ Neurobiol 2009, 36:592-602.

73. Ancuta P, Kamat A, Kunstman KJ, Kim EY, Autissier P, Wurcel A, Zaman T, Stone D, Mefford M, Morgello S, Singer EJ, Wolinsky SM, Gabuzda D: Microbial translocation is associated with increased monocyte activation and dementia in AIDS patients. PLoS One 2008, 3:e2516

74. Brenchley JM, Price DA, Douek DC: HIV disease: fallout from a mucosal catastrophe? Nat Immunol 2006, 7:235-239.

75. Brenchley JM, Price DA, Schacker TW, Asher TE, Silvestri G, Rao S, Kazzaz Z, Bornstein E, Lambotte O, Altmann D, Blazar BR, Rodriguez B, TeixeiraJohnson L, Landay A, Martin JN, Hecht FM, Picker LJ, Lederman MM, Deeks SG, Douek DC: Microbial translocation is a cause of systemic immune activation in chronic HIV infection. Nat Med 2006, 12:1365-1371.

76. Wang $H$, Sun J, Goldstein H: Human immunodeficiency virus type 1 infection increases the in vivo capacity of peripheral monocytes to cross the blood-brain barrier into the brain and the in vivo sensitivity of the blood-brain barrier to disruption by lipopolysaccharide. J Virol 2008, 82:7591-7600.

77. Bazan JF, Bacon KB, Hardiman G, Wang W, Soo K, Rossi D, Greaves DR, Zlotnik A, Schall TJ: A new class of membrane-bound chemokine with a CX3C motif. Nature 1997, 385:640-644.

78. Kaul M, Garden GA, Lipton SA: Pathways to neuronal injury and apoptosis in HIV-associated dementia. Nature 2001, 410:988-994.

79. Power C, McArthur JC, Nath A, Wehrly K, Mayne M, Nishio J, Langelier T, Johnson RT, Chesebro B: Neuronal death induced by brain-derived human immunodeficiency virus type 1 envelope genes differs between demented and nondemented AIDS patients. J Virol 1998, 72:9045-9053

80. Nottet HS, Persidsky Y, Sasseville VG, Nukuna AN, Bock P, Zhai QH, Sharer $L R$, McComb RD, Swindells S, Soderland C, Gendelman HE: Mechanisms for the transendothelial migration of HIV-1-infected monocytes into brain. J Immunol 1996, 156:1284-1295.

81. Gray F, Belec L, Chretien F, Dubreuil-Lemaire ML, Ricolfi F, Wingertsmann $L$, Poron F, Gherardi R: Acute, relapsing brain oedema with diffuse blood-brain barrier alteration and axonal damage in the acquired immunodeficiency syndrome. Neuropathol App/ Neurobiol 1998, 24:209-216.

82. Petito CK, Cash KS: Blood-brain barrier abnormalities in the acquired immunodeficiency syndrome: immunohistochemical localization of serum proteins in postmortem brain. Ann Neurol 1992, 32:658-666.

83. Maclean AG, Belenchia GE, Bieniemy DN, Moroney-Rasmussen TA, Lackner AA: Simian immunodeficiency virus disrupts extended lengths of the blood--brain barrier. J Med Primatol 2005, 34:237-242.

84. Dallasta LM, Pisarov LA, Esplen JE, Werley JV, Moses AV, Nelson JA, Achim $\mathrm{CL}$ : Blood-brain barrier tight junction disruption in human immunodeficiency virus-1 encephalitis. Am J Pathol 1999, 155:1915-1927.

85. Persidsky Y, Heilman D, Haorah J, Zelivyanskaya M, Persidsky R, Weber GA, Shimokawa H, Kaibuchi K, IkezU T: Rho-mediated regulation of tight junctions during monocyte migration across the blood-brain barrier in HIV-1 encephalitis (HIVE). Blood 2006, 107:4770-4780.

86. Luabeya MK, Dallasta LM, Achim CL, Pauza CD, Hamilton RL: Blood-brain barrier disruption in simian immunodeficiency virus encephalitis. Neuropathol App/ Neurobiol 2000, 26:454-462.

87. Mankowski JL, Queen SE, Kirstein LM, Spelman JP, Laterra J, Simpson IA, Adams RJ, Clements JE, Zink MC: Alterations in blood-brain barrier glucose transport in SIV-infected macaques. J Neurovirol 1999, 5:695-702.

88. Khan NA, Di Cello F, Stins M, Kim KS: Gp120-mediated cytotoxicity of human brain microvascular endothelial cells is dependent on p38 mitogen-activated protein kinase activation. J Neuroviro/ 2007, 13:242-251

89. Marshall DC, Wyss-Coray T, Abraham CR: Induction of matrix metalloproteinase-2 in human immunodeficiency virus-1 glycoprotein 120 transgenic mouse brains. Neurosci Lett 1998, 254:97-100.

90. Boehme SA, Lio FM, Maciejewski-Lenoir D, Bacon KB, Conlon PJ: The chemokine fractalkine inhibits Fas-mediated cell death of brain microglia. J Immuno/ 2000, 165:397-403.

91. Gonzalez E, Rovin BH, Sen L, Cooke G, Dhanda R, Mummidi S, Kulkarni H, Bamshad MJ, Telles V, Anderson SA, Walter EA, Stephan KT, Deucher M, Mangano A, Bologna R, Ahuja SS, Dolan MJ, Ahuja SK: HIV-1 infection and AIDS dementia are influenced by a mutant MCP-1 allele linked to increased monocyte infiltration of tissues and MCP-1 levels. Proc Nat/ Acad Sci USA 2002, 99:13795-13800.

92. El-Hage N, Wu G, Ambati J, Bruce-Keller AJ, Knapp PE, Hauser KF: CCR2 mediates increases in glial activation caused by exposure to HIV-1 Tat and opiates. J Neuroimmunol 2006, 178:9-16.

93. El-Hage N, Wu G, Wang J, Ambati J, Knapp PE, Reed JL, Bruce-Keller AJ, Hauser KF: HIV-1 Tat and opiate-induced changes in astrocytes promote chemotaxis of microglia through the expression of MCP-1 and alternative chemokines. Glia 2006, 53:132-146.

94. Eugenin EA, Osiecki K, Lopez L, Goldstein H, Calderon TM, Berman JW: CCL2/monocyte chemoattractant protein-1 mediates enhanced transmigration of human immunodeficiency virus (HIV)-infected leukocytes across the blood-brain barrier: a potential mechanism of HIV-CNS invasion and NeuroAIDS. J Neurosci 2006, 26:1098-1106.

95. Gu L, Rutledge B, Fiorillo J, Ernst C, Grewal I, Flavell R, Gladue R, Rollins B: In vivo properties of monocyte chemoattractant protein-1. J Leukoc Biol 1997, 62:577-580

96. Cinque P, Vago L, Mengozzi M, Torri V, Ceresa D, Vicenzi E, Transidico P, Vagani A, Sozzani S, Mantovani A, Lazzarin A, Poli G: Elevated cerebrospinal fluid levels of monocyte chemotactic protein-1 correlate with HIV-1 encephalitis and local viral replication. Aids 1998, 12:1327-1332

97. Conant K, Garzino-Demo A, Nath A, McArthur JC, Halliday W, Power C, Gallo RC, Major EO: Induction of monocyte chemoattractant protein-1 in HIV-1 Tat-stimulated astrocytes and elevation in AIDS dementia. Proc Natl Acad Sci USA 1998, 95:3117-3121.

98. Kelder W, MCArthur JC, Nance-Sproson T, McClernon D, Griffin DE: Betachemokines MCP- 1 and RANTES are selectively increased in cerebrospinal fluid of patients with human immunodeficiency virusassociated dementia. Ann Neurol 1998, 44:831-835.

99. Sozzani S, Introna M, Bernasconi S, Polentarutti N, Cinque P, Poli G, Sica A, Mantovani A: MCP-1 and CCR2 in HIV infection: regulation of agonist and receptor expression. J Leukoc Biol 1997, 62:30-33.

100. Zink MC, Coleman GD, Mankowski JL, Adams RJ, Tarwater PM, Fox K, Clements JE: Increased macrophage chemoattractant protein-1 in cerebrospinal fluid precedes and predicts simian immunodeficiency virus encephalitis. J Infect Dis 2001, 184:1015-1021.

101. Sanders VJ, Pittman CA, White MG, Wang G, Wiley CA, Achim CL Chemokines and receptors in HIV encephalitis. Aids 1998 12:1021-1026

102. Buch S, Sui Y, Potula R, Pinson D, Adany I, Li Z, Huang M, Li S, Dhillon N, Major E, Narayan O: Role of interleukin-4 and monocyte chemoattractant protein-1 in the neuropathogenesis of X4 simian human immunodeficiency virus infection in macaques. $J$ Neurovirol 2004, 10(Suppl 1):118-124. 
103. Hicks A, Potula R, Sui YJ, Villinger F, Pinson D, Adany I, Li Z, Long C, Cheney P, Marcario J, Novembre F, Mueller N, Kumar A, Major E, Narayan O, Buch S: Neuropathogenesis of lentiviral infection in macaques: roles of CXCR4 and CCR5 viruses and interleukin-4 in enhancing monocyte chemoattractant protein-1 production in macrophages. Am J Pathol 2002, 161:813-822.

104. Persidsky Y, Ghorpade A, Rasmussen J, Limoges J, Liu XJ, Stins M, Fiala M, Way D, Kim KS, Witte MH, Weinand M, Carhart L, Gendelman HE: Microglial and astrocyte chemokines regulate monocyte migration through the blood-brain barrier in human immunodeficiency virus-1 encephalitis. Am J Pathol 1999, 155:1599-1611.

105. Malik M, Chen YY, Kienzle MF, Tomkowicz BE, Collman RG, Ptasznik A: Monocyte migration and LFA-1-mediated attachment to brain microvascular endothelia is regulated by SDF-1 alpha through Lyn kinase. J Immunol 2008, 181:4632-4637.

106. Samah B, Porcheray F, Gras G: Neurotrophins modulate monocyte chemotaxis without affecting macrophage function. Clin Exp Immunol 2008, 151:476-486.

107. Samah B, Porcheray F, Dereuddre-Bosquet N, Gras G: Nerve growth factor stimulation promotes CXCL-12 attraction of monocytes but decreases human immunodeficiency virus replication in attracted population. J Neurovirol 2009, 15:71-80.

108. Wu DT, Woodman SE, Weiss JM, McManus CM, D'Aversa TG, Hesselgesser J, Major EO, Nath A, Berman JW: Mechanisms of leukocyte trafficking into the CNS. J Neurovirol 2000, 6(Suppl 1):S82-85

109. Gendelman HE, Ding S, Gong N, Liu J, Ramirez SH, Persidsky Y, Mosley RL, Wang T, Volsky DJ, Xiong $\mathrm{H}$ : Monocyte chemotactic protein-1 regulates voltage-gated $\mathrm{K}+$ channels and macrophage transmigration. J Neuroimmune Pharmacol 2009, 4:47-59.

110. Chaudhuri A, Duan F, Morsey B, Persidsky Y, Kanmogne GD: HIV-1 activates proinflammatory and interferon-inducible genes in human brain microvascular endothelial cells: putative mechanisms of bloodbrain barrier dysfunction. J Cereb Blood Flow Metab 2008, 28:697-711.

111. Yang B, Akhter S, Chaudhuri A, Kanmogne GD: HIV-1 gp120 induces cytokine expression, leukocyte adhesion, and transmigration across the blood-brain barrier: modulatory effects of STAT1 signaling. Microvasc Res 2009, 77:212-219.

112. Chaudhuri A, Yang B, Gendelman HE, Persidsky Y, Kanmogne GD: STAT1 signaling modulates HIV-1-induced inflammatory responses and leukocyte transmigration across the blood-brain barrier. Blood 2008, 111:2062-2072.

113. Kanmogne GD, Schall K, Leibhart J, Knipe B, Gendelman HE, Persidsky Y: HIV-1 gp120 compromises blood-brain barrier integrity and enhances monocyte migration across blood-brain barrier: implication for viral neuropathogenesis. J Cereb Blood Flow Metab 2007, 27:123-134.

114. Ricardo-Dukelow M, Kadiu I, Rozek W, Schlautman J, Persidsky Y, Ciborowski P, Kanmogne GD, Gendelman HE: HIV-1 infected monocytederived macrophages affect the human brain microvascular endothelial cell proteome: new insights into blood-brain barrier dysfunction for HIV-1-associated dementia. J Neuroimmunol 2007 185:37-46.

115. Persidsky $Y$, Stins M, Way D, Witte MH, Weinand M, Kim KS, Bock P, Gendelman HE, Fiala M: A model for monocyte migration through the blood-brain barrier during HIV-1 encephalitis. J Immunol 1997, 158:3499-3510.

116. Dohgu S, Banks WA: Lipopolysaccharide-enhanced transcellular transport of HIV-1 across the blood-brain barrier is mediated by the p38 mitogen-activated protein kinase pathway. Exp Neurol 2008, 210:740-749.

117. Owe-Young R, Webster NL, Mukhtar M, Pomerantz RJ, Smythe G, Walker D, Armati PJ, Crowe SM, Brew BJ: Kynurenine pathway metabolism in human blood-brain-barrier cells: implications for immune tolerance and neurotoxicity. J Neurochem 2008, 105:1346-1357.

118. Guillemin GJ, Kerr SJ, Smythe GA, Smith DG, Kapoor V, Armati PJ, Croitoru J, Brew BJ: Kynurenine pathway metabolism in human astrocytes: a paradox for neuronal protection. J Neurochem 2001, 78:842-853.

119. Guillemin GJ, Kerr SJ, Brew BJ: Involvement of quinolinic acid in AIDS dementia complex. Neurotox Res 2005, 7:103-123.

120. Carlin JM, Borden EC, Sondel PM, Byrne GI: Interferon-induced indoleamine 2,3-dioxygenase activity in human mononuclear phagocytes. J Leukoc Biol 1989, 45:29-34.
121. Hurwitz AA, Berman JW, Lyman WD: The role of the blood-brain barrier in HIV infection of the central nervous system. Adv Neuroimmunol 1994, 4:249-256.

122. Sasseville VG, Newman W, Brodie SJ, Hesterberg P, Pauley D, Ringler DJ: Monocyte adhesion to endothelium in simian immunodeficiency virus-induced AIDS encephalitis is mediated by vascular cell adhesion molecule-1/alpha 4 beta 1 integrin interactions. Am J Pathol 1994, 144:27-40.

123. Ramirez SH, Heilman D, Morsey B, Potula R, Haorah J, Persidsky Y Activation of peroxisome proliferator-activated receptor gamma (PPARgamma) suppresses Rho GTPases in human brain microvascular endothelial cells and inhibits adhesion and transendothelial migration of HIV-1 infected monocytes. J Immuno/ 2008, 180:1854-1865.

124. Ivey NS, Renner NA, Moroney-Rasmussen T, Mohan M, Redmann RK, Didier PJ, Alvarez X, Lackner AA, Maclean AG: Association of FAK activation with lentivirus-induced disruption of blood-brain barrier tight junction-associated ZO-1 protein organization. J Neurovirol 2009:1-12.

125. Nakamuta S, Endo H, Higashi Y, Kousaka A, Yamada H, Yano M, Kido H: Human immunodeficiency virus type $1 \mathrm{gp} 120$-mediated disruption of tight junction proteins by induction of proteasome-mediated degradation of zonula occludens- 1 and -2 in human brain microvascular endothelial cells. J Neurovirol 2008, 14:186-195.

126. Zhong Y, Smart EJ, Weksler B, Couraud PO, Hennig B, Toborek M: Caveolin-1 regulates human immunodeficiency virus-1 Tat-induced alterations of tight junction protein expression via modulation of the Ras signaling. J Neurosci 2008, 28:7788-7796.

127. Berman JW, Carson MJ, Chang L, Cox BM, Fox HS, Gonzalez RG, Hanson GR, Hauser KF, Ho WZ, Hong JS, Major EO, Maragos WF, Masliah E, McArthur JC, Miller DB, Nath A, O'Callaghan JP, Persidsky Y, Power C, Rogers TJ, Royal W: NeuroAIDS, drug abuse, and inflammation: building collaborative research activities. J Neuroimmune Pharmacol 2006, 1:351-399.

128. Bouwman FH, Skolasky RL, Hes D, Selnes OA, Glass JD, Nance-Sproson TE, Royal W, Dal Pan GJ, McArthur JC: Variable progression of HIV-associated dementia. Neurology 1998, 50:1814-1820.

129. Kapadia F, Vlahov D, Donahoe RM, Friedland G: The role of substance abuse in HIV disease progression: reconciling differences from laboratory and epidemiologic investigations. Clin Infect Dis 2005, 41:1027-1034

130. Kopnisky KL, Bao J, Lin YW: Neurobiology of HIV, psychiatric and substance abuse comorbidity research: workshop report. Brain Behav Immun 2007, 21:428-441.

131. Mahajan SD, Aalinkeel R, Sykes DE, Reynolds JL, Bindukumar B, Fernandez SF, Chawda R, Shanahan TC, Schwartz SA: Tight junction regulation by morphine and HIV-1 tat modulates blood-brain barrier permeability. J Clin Immunol 2008, 28:528-541.

132. Mahajan SD, Aalinkeel R, Sykes DE, Reynolds JL, Bindukumar B, Adal A, Qi M, Toh J, Xu G, Prasad PN, Schwartz SA: Methamphetamine alters blood brain barrier permeability via the modulation of tight junction expression: Implication for HIV-1 neuropathogenesis in the context of drug abuse. Brain Res 2008, 1203:133-148.

133. Dhillon NK, Peng F, Bokhari S, Callen S, Shin SH, Zhu X, Kim KJ, Buch SJ: Cocaine-mediated alteration in tight junction protein expression and modulation of CCL2/CCR2 axis across the blood-brain barrier: implications for HIV-dementia. J Neuroimmune Pharmaco/ 2008, 3:52-56.

134. Fiala M, Gan XH, Zhang L, House SD, Newton T, Graves MC, Shapshak P, Stins M, Kim KS, Witte M, Chang SL: Cocaine enhances monocyte migration across the blood-brain barrier. Cocaine's connection to AIDS dementia and vasculitis? Adv Exp Med Biol 1998, 437:199-205.

135. Lu TS, Avraham HK, Seng S, Tachado SD, Koziel H, Makriyannis A, Avraham S: Cannabinoids inhibit HIV-1 Gp120-mediated insults in brain microvascular endothelial cells. J Immunol 2008, 181:6406-6416.

136. Shiu C, Barbier E, Di Cello F, Choi HJ, Stins M: HIV-1 gp120 as well as alcohol affect blood-brain barrier permeability and stress fiber formation: involvement of reactive oxygen species. Alcohol Clin Exp Res 2007, 31:130-137.

137. Narayan O, Wolinsky JS, Clements JE, Strandberg JD, Griffin DE, Cork LC: Slow virus replication: the role of macrophages in the persistence and expression of visna viruses of sheep and goats. J Gen Virol 1982, 59:345-356. 
138. Peluso R, Haase A, Stowring L, Edwards M, Ventura P: A Trojan Horse mechanism for the spread of visna virus in monocytes. Virology 1985, 147:231-236.

139. Spudich SS, Nilsson AC, Lollo ND, Liegler TJ, Petropoulos CJ, Deeks SG, Paxinos EE, Price RW: Cerebrospinal fluid HIV infection and pleocytosis: relation to systemic infection and antiretroviral treatment. BMC Infect Dis 2005, 5:98.

140. Sinclair E, Ronquillo R, Lollo N, Deeks SG, Hunt P, Yiannoutsos CT, Spudich $S$, Price RW: Antiretroviral treatment effect on immune activation reduces cerebrospinal fluid HIV-1 infection. J Acquir /mmune Defic Syndr 2008, 47:544-552.

doi: $10.1186 / 1742-4690-7-30$

Cite this article as: Gras and Kaul, Molecular mechanisms of neuroinvasion by monocytes-macrophages in HIV-1 infection Retrovirology 2010, 7:30

Submit your next manuscript to BioMed Central and take full advantage of:

- Convenient online submission

- Thorough peer review

- No space constraints or color figure charges

- Immediate publication on acceptance

- Inclusion in PubMed, CAS, Scopus and Google Scholar

- Research which is freely available for redistribution

Submit your manuscript at www.biomedcentral.com/submit
() BioMed Central 